\title{
Global Views, Personal Perspectives: Connecting to Self as Scholar
}

\author{
Nicola Simmons \\ University of Waterloo
}

A global view requires not only a broader perspective, but also greater depth to anchor it firmly. In increasingly changing contexts, are we connected to ourselves in a way that feeds our spirits and nourishes our work? A professional sphere based only on research and practice risks being unbalanced and may jeopardize our well-being as academics. The activities outlined in this paper encourage you to add a third support: integration of self as scholar towards a more balanced perspective.

\section{Balance in Scholarship}

$\mathrm{T}$ his year's Society for Teaching and Learning in Higher Education conference theme, $A$ World of Learning, was in part about the impact of globalization in higher education - a timely choice, given international issues of credentials, credit transfer, and accountability. At the same time, class sizes and corresponding workload and its pace continue to increase, and technologysupported multi-tasking has become the expected norm. Is the world truly getting smaller, or are we becoming smaller within it?

In a pre-conference workshop, I proposed that a global view of scholarship requires not only greater breadth of vision, but also greater depth, particularly about who we are and how our perspectives help us find fulfillment in our work. A sense of self as scholar is critical to success, particularly as we work to navigate the stress of our often rapidly changing contexts.

'Evidence-based practice' - an integration of research and teaching - is likely a familiar phrase. Indeed, one of the strengths of the relatively new field of the Scholarship of Teaching and Learning (SoTL) is that it naturally connects these two foci. In my mind, however, this integration leaves out something of critical importance. Just as I advise faculty planning their courses to consider the three learning domains (cognitive, psychomotor, and affective), I suggest practitioners consider how these three, which could also be thought of as theory, practice, and self, intersect in their own reflective practice. I note that better balance can be achieved with three points - which will always be in the same plane. Palmer (1998) advised academics to consider the spirit of teaching; 
Brookfield (1995) proposed teaching authentically. How often, however, do we think about integrating self as scholar into both teaching and research to create a symbiotic triad of scholarship?

The conference workshop grew from a desire to provide opportunities for others to critically analyze their professional roles, their beliefs and values about those roles, and where they might draw strength and reduce stress in those roles. To this end, we engaged in several activities to help uncover assumptions and unexamined perspectives. In the remainder of this paper I will briefly describe some of these activities, including role/identity graphing, 10 roles, supports and detractors, and a variation on Kompf's (1993) lifemapping. In each case, I have provided space for you to try the activities as you read.

\section{Role/Identity Pie Graphs}

This exercise asks you to create pie graphs to compare how your work life is now and how you would like it to be. Spend time thinking about what you put in each circle, and what percentage of your time it occupies. How can you reduce areas that occupy much of your time now but that you would like to replace with more meaningful or rewarding activities?

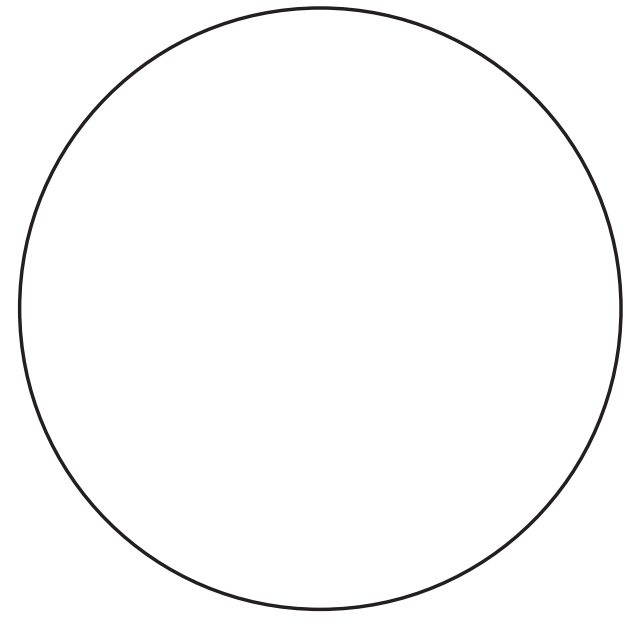

How my work life is now

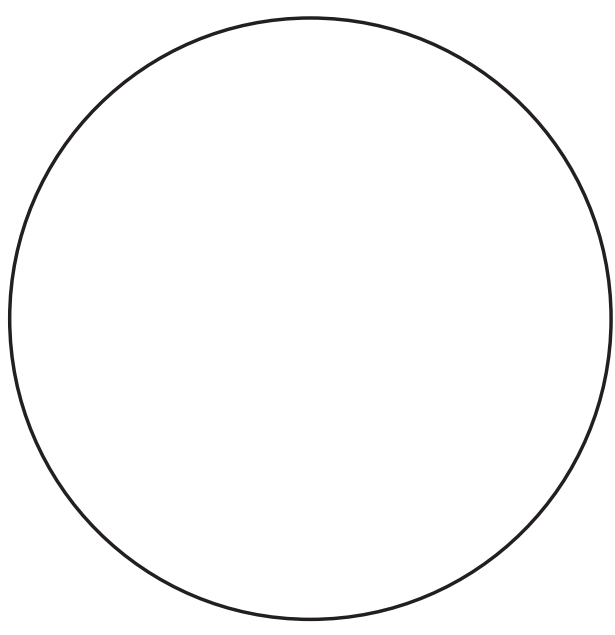

How I'd like it to be

In my own example, I found that even after including 35 hours a week of work, seven hours sleep per night, driving to work, an hour of physical activity a day, eating, making meals, ferrying kids around, I still had 40 hours left over to spend however I want. I could so easily (and perhaps you already do) fill those extra 40 hours with more work, but I know that's not how I will be my most productive and fulfilled. 


\section{Ten Roles}

Another activity that may produce surprising insights is to consider one's existing roles. Begin by listing descriptors of ten roles (which can also be thought of as hats we wear or aspects of our professional personality, e.g., developmentalist, jester, mentor, etc.). Now, cross off three words you can live without. Think about keeping the items essential to who you are, and deleting the others. Done? Now cross off three more. Now two more (it's ok - you're not really giving them up - it's just on paper). Look at what's left. Does one word describe you better? If so, circle it. Or, is there a new word that would encompass both the remaining words? Think about what this says about who you are - and what 'roles' you were able to give up. An integrated sense of who one is in a particular job can help make the work feel less fractured and in turn, more focused.

1.

2.

3.

4.

5.
6.

7.

8.

9.

10.

\section{Supports and Detractors}

Another tool for reflection is to list factors that contribute to a sense of personal and professional wellness and those that detract from that sense.
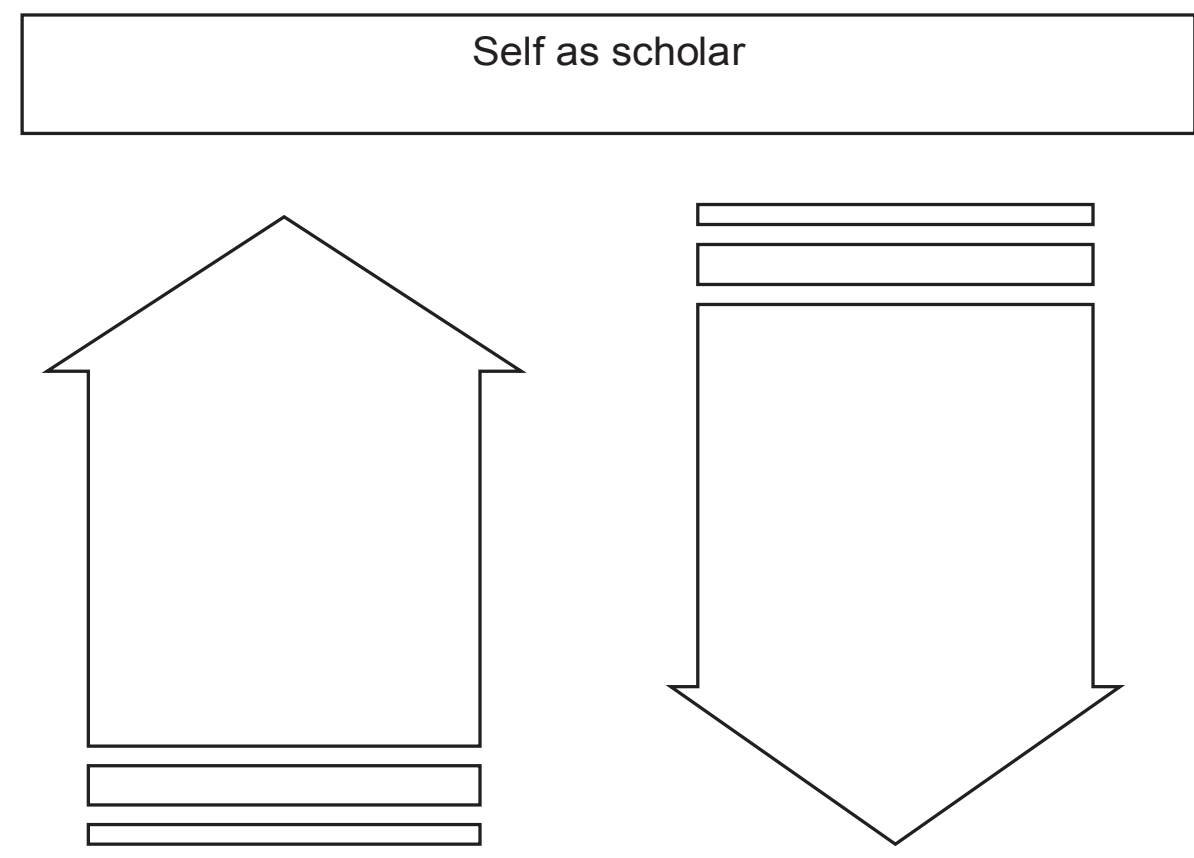

Now consider the lists you have made on each side of the graphic. In an ideal world, the factors in your life that contribute to your personal and professional wellness would far outweigh those that detract from it. What can you do to increase the positive factors, and where possible, mitigate the negative ones? 


\section{Snakes and Ladders: Game of Life}

Lifemapping, as described by Kompf (1993), involves listing significant life events along a timeline and rating them as -10 to +10 for their life impact at the time of the event and their life impact now. Changes in impact ratings can help you understand patterns of personal growth and reflecting on past events and your response to them can help in anticipating future events and life paths. In working with this activity over the years, I have found some people find it too linear. This led me to the idea that a snakes and ladders format could better support the graphing of overlapping events. (I have since found that snakes and ladders originated in India, where it was used to teach ethics and moral values about life.)

Pick a location for where you are now. Draw in your own snakes and ladders for incidents/times that have affected where you are now, as well as for what will have impact in the future. Use snakes as downward paths to represent events/issues/persons that have a negative impact, and ladders as upward paths for events/ issues/persons having a positive impact.

\begin{tabular}{|c|c|c|c|c|c|c|c|c|c|}
\hline $\begin{array}{l}100 \\
\text { Finish }\end{array}$ & 99 & 98 & 97 & 96 & 95 & 94 & 93 & 92 & 91 \\
\hline 81 & 82 & 83 & 84 & 85 & 86 & 87 & 88 & 89 & 90 \\
\hline 80 & 79 & 78 & 77 & 76 & 75 & 74 & 73 & 72 & 71 \\
\hline 61 & 62 & 63 & 64 & 65 & 66 & 67 & 68 & 69 & 70 \\
\hline 60 & 59 & 58 & 57 & 56 & 55 & 54 & 53 & 52 & 51 \\
\hline 41 & 42 & 43 & 44 & 45 & 46 & 47 & 48 & 49 & 50 \\
\hline 40 & 39 & 38 & 37 & 36 & 35 & 34 & 33 & 32 & 31 \\
\hline 21 & 22 & 23 & 24 & 25 & 26 & 27 & 28 & 29 & 30 \\
\hline 20 & 19 & 18 & 17 & 16 & 15 & 14 & 13 & 12 & 11 \\
\hline $\begin{array}{l}1 \\
\text { Start }\end{array}$ & 2 & 3 & 4 & 5 & 6 & 7 & 8 & 9 & 10 \\
\hline
\end{tabular}




\section{Final Thoughts}

Agryis asserts the value of taking time to examine beliefs and values, saying that those who don't are "like a thermostat that corrects error (the room is too hot or too cold) without questioning (why am I set at 68 degrees?)" (cited in Apps, 1994, p. 91). The challenge this creates is that one is constantly reacting to the changing environment rather than analyzing and guiding the changes. This puts us in a mode of reactivity rather than creativity. Creativity releases and expands our available energy; reactivity leaves us always feeling like we are playing catch up - with no hope of ever quite doing so. As long ago as 1987, Seldin and others wrote about the challenges of stress faced by academics, and there is no reason to think that the stress has abated. Perhaps we're now simply too busy to talk or write about it - or even to spend time reflecting on our own stress?

We would do well to remember that scholarship has its etymological roots in schola, meaning, "rest, employment of leisure time...originally a 'pause" (Skeat, 1993, p. 418). Bruce Chatwin's (1987) words in The Songlines serve as a poignant reminder of the importance of attending to what does and does not give us strength and fulfilment in our personal and professional roles:

A white explorer in Africa, anxious to press ahead with his journey, paid his porters for a series of forced marches. But they, almost within reach of their destination, set down their bundles and refused to budge. No amount of extra payment would convince them otherwise. They said they had to wait for their souls to catch up. (p. 230)

\section{References}

Apps, J. W. (1994). Examining beliefs and values about leadership. In J. W. Apps (Ed.), Leadership for the emerging age: Transforming practice in adult and continuing education (pp. 85-89). San Francisco: Jossey-Bass.
Brookfield, S. D. (1995). Becoming a critically reflective teacher. San Francisco: Jossey-Bass.

Chatwin, B. (1987). The songlines. New York: Penguin Books.

Kompf, M. (1993). Construing teachers' personal development: Reflections on landmark events through career mapping. In C. Day, J. Calderhead, \& P. Denicolo (Eds.), Research on teacher thinking: Understanding professional development (pp. 167-176). London: The Falmer Press.

Palmer, P. (1998). The courage to teach. San Francisco: Jossey-Bass.

Seldin, P. (1987). Research findings on causes of academic stress. In P. Seldin (Vol. Ed.), Coping with faculty stress: Vol. 29. New Directions for Teaching and Learning. San Francisco: JosseyBass.

Skeat, W. W. (1993). The concise dictionary of English etymology. Ware: Hertfordshire: Wordsworth Editions.

\section{Biography}

Nicola Simmons is a Research and Evaluation Consultant at the University of Waterloo, Ontario, where she supports faculty research about teaching and learning and pursues her own research on developing identity as scholars. 